\title{
Effect of stocking density on the expression of glucose transporter protein 1 and other physiological factors in the Lake Victoria Nile tilapia, Oreochromis niloticus $(\mathrm{L}$.
}

\author{
Ben Ochieng' Aketch • Paul Oyieng' Ang'ienda • \\ John Odero Radull $\cdot$ Eliud Nyandago Waindi
}

Received: 11 March 2014/ Accepted: 12 June 2014/Published online: 15 July 2014

(C) The Author(s) 2014. This article is published with open access at Springerlink.com

\begin{abstract}
Fish farmers have a tendency of employing high stocking density (HSD) as a means of increasing productivity. However, HSD is a chronic stressor that is likely to lower profitability of fish farming if not implemented properly. HSD induces stress which in turn elevates sequentially the levels of plasma cortisol and glucose. The resultant glucose is distributed to various tissues by glucose transporter protein (GLUTs) to restore normalcy. GLUT 1, transmembrane protein found in erythrocytes, is responsible for import and export of glucose in red blood cells. However, knowledge on how chronic stress impact glucose and GLUT 1 protein in fish subjected to HSD is still unclear. In this study, effect of HSD on the expression of GLUT 1 in Nile tilapia was investigated in an attempt to elucidate the role of GLUT 1 in glucose metabolism during chronic stress. Fish were reared for 4 weeks at 1.5 and $4.5 \mathrm{~kg} / \mathrm{m}^{3}$ for low stocking density (LSD) and HSD, respectively. Four physiological parameters were determined from the blood samples obtained from fish at the end of experiment. At $p<0.05$, there were significant differences between fish reared at HSD and LSD in plasma cortisol level $(72.1 \pm 5.9 \mathrm{ng} / \mathrm{ml}$ and $37.5 \pm 4.6 \mathrm{ng} / \mathrm{ml})$; blood glucose level $(136.00 \pm 1.3 \mathrm{mg} / \mathrm{dL}$ and $70.2 \pm 1.0 \mathrm{mg} / \mathrm{dL})$; erythrocytes count $\left(7.2 \pm 0.5 \times 106 \mathrm{~mm}^{-3}\right.$ and $\left.2.1 \pm 0.4 \times 106 \mathrm{~mm}^{-3}\right)$; and plasma GLUT 1 level $(1.40 \pm 0.17 \mathrm{rbi}$ and $0.81 \pm 0.07 \mathrm{rbi})$, respectively. HSD induced elevation of plasma cortisol level, blood glucose level, erythrocytes count and GLUT 1 level. These elevated physiological factors and particularly GLUT 1 can be used as a cellular stress biomarker in fish farming and aquaculture.
\end{abstract}

Keywords Cellular $\cdot$ Fish farming $\cdot$ GLUT $1 \cdot$ Stocking density $\cdot$ Stress biomarker

\section{Introduction}

Nile tilapia Oreochromis niloticus (Linnaeus 1758) is one of the most preferred species for aquaculture owing to its ability to withstand harsh environmental cues, high reproductive ability and better growth performances and high market demand as a cheap source of protein (El-Sayed 2006: Chakraborty et al. 2010). Maximum

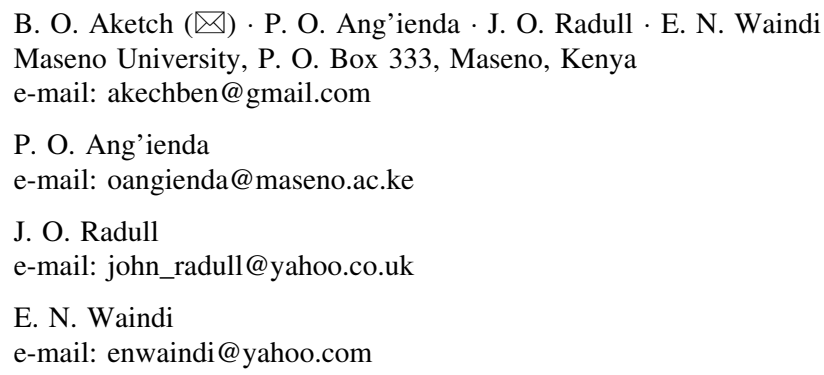


utilization of available resources to increase stock production is commonplace in fish-farming practice. High stocking density (HSD) is one such method that has been used to increase fish productivity (Chakraborty et al. 2010; Salama et al. 2006). However, HSD causes chronic stress to fish (Montero et al. 2001; El-Khaldi 2010) leading to decreased growth, fin erosion, disruption of reproductive capacities, and increase in disease susceptibility and mortality (Pickering 1993; Schreck 1996).

When faced with stress, Nile tilapia like most fish will employ a number of mechanisms to alleviate perturbations (Wendelaar 1997). Initially, there is increase in the plasma levels of cortisol, which is normally used as primary indicator of the degree of stress experienced by fish (Pickering and Pottinger 1989; Barton and Iwama 1991; Pickering 1993; Wendelaar 1997; Mommsen et al. 1999; Barton 2002). Elevation of plasma cortisol levels is responsible for various secondary physiological adjustments experienced by teleost fish (Pickering and Pottinger 1989; Pickering 1993; Mommsen et al. 1999; Caipang 2012). These include changes in blood parameters, plasma glucose, free fatty acids, protein synthesis and hydromineral balance (Schreck et al. 2001; Barton 2002). Cortisol affects the metabolism of carbohydrates, proteins and lipids. Generally, Cortisol is hyperglycemic, and mediates increased liver metabolic capacity such as glycogenolysis, glycolysis and gluconeogenesis; thereby elevating blood glucose levels that produce a burst of energy which prepares the fish for an emergency situation (Pickering and Pottinger 1989; Pickering 1993; Mommsen et al. 1999; Schreck et al. 2001; Wiseman et al. 2007). Thus, a high blood level of glucose is used as secondary indicator of stress (Barreto and Volpato 2006). The resultant glucose is transported to different cells and tissues of the host to be used as cellular fuel to restore normalcy. Movement of glucose across the plasma membrane of red blood cells is mediated through facultative glucose transporter protein 1 (Samih et al. 2000; Joost and Thorens 2001; Zhao and Keating 2007). Currently, there are 14 members of GLUT protein family (Balmaceda-Aguilera et al. 2012; Pyla et al. 2013). GLUT 1 protein has been detected in tissues of teleost fish (Wright et al. 2000; Moon 2001). In Nile tilapia, it has been observed that GLUT 1 is widely distributed in various tissues (Hrytsenko et al. 2010); it is strongly expressed in erythrocytes and brain whereas liver, heart, and muscle all have exhibited low levels of expression (Wright et al. 1998; Klepper et al. 1999). GLUT 1 is a stress-inducible protein of the glucose-regulated proteins superfamily (Wertheimer et al. 1991) of which the expression level is modulated by stress (Hwang and Ismail-Beigi 2001). Teleost fish, including O. niloticus, are glucose intolerant, with very low rates of plasma glucose clearance, due to peripheral resistance to hypoglycemic effect of insulin on glucose and limited numbers of glucose transporters (Mommsen and Plisetskaya 1991; Wright et al. 1998; Moon 2001). However, there is indirect evidence showing that glucose entry into cells is modulated by members of the GLUT family in fish. For instance, Wright et al. (1998) reported the presence of GLUT 1 protein in heart and brain of tilapia; and increased glucose uptake and metabolism in transgenic trout embryos overexpressing human GLUT 1. Hrytsenko et al. (2010) analyzed the effect of acute glucose injection and feeding on the level of GLUT 1 mRNA expression in Nile tilapia, and found that both food and glucose upregulated GLUT 1 mRNA levels in white muscle. However, little is known about how chronic stress affects levels of GLUT 1 in Nile tilapia. In this paper, we present a direct evidence of the involvement of GLUT 1 in Nile tilapia subjected to HSD-induced stress. The fish-stocked cultures at HSD showed a higher expression of GLUT 1 protein than those cultured at LSD as shown by Western blot immunoreactivity of the SDS-PAGE resolved fish plasma proteins against IgG primary antibody for Nile tilapia GLUT 1. The levels of both cortisol and glucose were also assayed and presented as a confirmation of HSD-induced stress.

\section{Materials and methods}

\section{Treatment system}

The fish for this study were originally obtained from Winam Gulf of Lake Victoria (latitudes $0^{\circ} 11.20 \mathrm{~N}-$ $1^{\circ} 12.60 \mathrm{~S}$ and longitudes $\left.33^{\circ} 45.70 \mathrm{E}-34^{\circ} 45.70 \mathrm{E}\right)$ and reared in the Department of Zoology, Maseno University, under tropical environmental conditions of $12 \mathrm{~h}$ of light and $12 \mathrm{~h}$ of darkness, and temperature of $27 \pm 1{ }^{\circ} \mathrm{C}$. Fish samples used in this study were the fifth generation of the parent stock. A total of 90 juvenile fish were caught from ponds and then transferred to a 1,000 1 tank and let to acclimatize to their new environment for 7 days before treatment commenced. Fish with an initial mean weight of $16.5 \pm 3.1 \mathrm{~g}$ were distributed randomly in six glass aquaria of 551 capacity for 4 weeks at two treatment 
Table 1 Proximate composition of ingredients (\% dry matter basis) which were mixed in the 9:1

\begin{tabular}{lcr}
\hline Ingredients & Maize bran & Fishmeal \\
\hline Dry matter & 90.48 & 90.17 \\
Crude protein & 11.98 & 56.80 \\
Ash & 3.93 & 11.47 \\
Ether extract & 54.22 & 12.68 \\
Crude fiber & 12.70 & 2.11 \\
\hline
\end{tabular}

densities ( 3 replicates/density treatment): $1.5 \mathrm{~kg} / \mathrm{m}^{3}$ (low stocking density $=\mathrm{LSD}, 5$ fish) and $4.5 \mathrm{~kg} / \mathrm{m}^{3}$ (HSD, 15 fish) per aquarium (Al-Jerian 1998; Al-Harbi and Siddiqui 2000). Each aquarium was equipped with aerator pump for continuous aeration. Feces and uneaten feed residues were siphoned out of the tank together with about one half of the water volume of the aquarium each day and replaced with clean water. During acclimation and throughout the treatment period, the fish in each aquarium were fed twice daily with maize bran supplemented with $10 \%$ fish protein (Rastrineobola argentea) at $20 \mathrm{~g} / \mathrm{kg}$ body weight as described by Ang'ienda et al. (2010). The composition of the feed is presented in Table 1. Water quality parameters such as dissolved oxygen, $\mathrm{pH}$, temperature, nitrite and total ammonia were monitored in situ throughout the study using Hydrolab DS5X Multiparameter Sonde (Hach Hydromet, USA).

Sample collection and storage

At the end of the experiment, five fish from each aquarium were randomly sampled using hand net and quickly anesthetized with 2-phenoxyethanol. Approximately, $2 \mathrm{ml}$ of blood was collected by cardiopuncture using a heparin-coated needle and syringe into EDTA-coated tubes. The blood samples were held on ice until all samples were collected. All samplings were completed within $5 \mathrm{~min}$ of fish removal from the aquarium. Blood glucose levels and erythrocyte count were determined from whole blood. The remaining blood was centrifuged at $5000 \mathrm{rpm}$ for $5 \mathrm{~min}$ to obtain plasma, which was then stored at $-20{ }^{\circ} \mathrm{C}$ until assayed according to the method of Barreto and Volpato (2006). Part of the supernatant was used to quantify protein concentration by BCA assay.

\section{Western blot analysis}

A volume of $10 \mu \mathrm{l}$ of plasma samples was loaded onto $12 \%$ polyacrylamide gel, and resolved by sodium dodecyl sulfate-polyacrylamide gel electrophoresis (SDS-PAGE) at $150 \mathrm{~V}$ for $2 \mathrm{~h}$ following the method of Laemmli (1970). The resolved bands on the gel were transferred onto a $0.2 \mu \mathrm{m}$ pore size nitrocellulose membrane at $17 \mathrm{~V}$ for $50 \mathrm{~min}$ with transfer buffer using a semi-dry transfer apparatus (Bio-Rad Trans-Blot, California, USA). Transfer membranes were blocked in $1 \times$ casein in Tween-20 Tris-buffered saline [TTBS; $17.4 \mathrm{mM}$ Tris- $\mathrm{HCl}, 2.64 \mathrm{mM}$ Tris Base, $0.5 \mathrm{M} \mathrm{NaCl}$, and $0.05 \%$ Tween-20 (v/v)] for $1 \mathrm{~h}$. Membranes were then rinsed once and soaked for $5 \mathrm{~min}$ in TTBS. The membranes were then incubated in a Mouse monoclonal IgG primary antibody for tilapia GLUT 1, in TTBS for $2 \mathrm{~h}$ at a dilution 1:5000 (Cat \# ab40084, Abcam, Cambridge, UK). After three, 5 min washes in TTBS, the membranes were incubated in Horse radish peroxidase (HRP) conjugated rabbit anti mouse IgG secondary antibody in TTBS for $1 \mathrm{~h}$ at a dilution 1:20000 (Cat \# ab6728, ABCAM, Cambridge, UK). After three 5 min washes in TTBS and one 5 min wash in Tris-buffered saline to remove Tween-20, the membranes were incubated for 1 min with enhanced chemiluminescence reagents Western blotting detecting system (Amersham, Chalfont, Bucks, UK) and exposed to Kodak X-OMATAR film for between 30 and $120 \mathrm{~s}$. The film was scanned at resolution of 300-400 dpi. The levels of GLUT 1 protein were quantified by ImageJ software (Heidebrecht et al. 2009) (NIH, USA) against the constant level of a $50 \mathrm{kDa} \beta$-Tubulin (Cat \# ab6046, ABCAM, Cambridge, UK) used as loading control. 
Blood parameters

Measurement of plasma cortisol by Enzyme-linked immunosorbent assay (ELISA)

The levels of plasma cortisol were measured using a commercially available ELISA-kit from NEOGEN CORP. (Lexington, KY, USA) according to manufacturer's instructions (Nakano et al. 2013).

\section{Blood glucose level}

Blood glucose level was measured by handheld MD $300^{\mathrm{TM}}$ glucose meter (MD Instruments Inc, USA). A single drop of blood was placed on the blood strip and inserted in the meter and reading recorded to the nearest $\mathrm{mg} / \mathrm{dl}$ according to the method described by Eames et al. (2010) and Wells and Pankhurst (1999).

\section{Erythrocyte count}

Erythrocyte counts were determined manually with the improved Neubauer counting chamber after the blood was diluted with Natt and Herrick's solution at 1:200, then counting the erythrocytes in five red blood cell squares of the improved Neubauer counting chamber (Campbell 1995).

Statistical analyses

All the experiments were performed in triplicate and the group means analyzed using paired Student's $t$ test of GraphPad prism5 statistical software (http://www.graphpad.com/prism/Prism.htm). The data were presented as mean \pm SEM. Data were considered significantly different at the level of $p<0.05$.

\section{Results}

Water quality parameters

Water parameters were measured and recorded as follows: temperature $27.0 \pm 1.0{ }^{\circ} \mathrm{C} ; \mathrm{pH} 7.3 \pm 0.2$; dissolved oxygen $5.0 \pm 0.3 \mathrm{mg} / \mathrm{l}$; nitrite $0.20 \pm 0.02 \mathrm{mg} / \mathrm{l}$; and total ammonia $0.04 \pm 0.01 \mathrm{mg} / \mathrm{l}$. These readings for the above-mentioned water parameters were within specific ranges recommended for fish growth (Boyd 1984). Therefore, it was assumed that the stress that affected the physiology of the fish in this study emanated only from stocking density treatment.

Measurement of plasma cortisol level, blood glucose level and erythrocyte count in Nile tilapia

High stocking density individuals had higher plasma cortisol level, blood glucose level and erythrocyte count than low stocking density individuals (Table 2). High levels of plasma cortisol and blood glucose, and raised numbers of erythrocytes in HSD individuals confirmed the presence of stress.

Table 2 Plasma cortisol, blood glucose, and erythrocyte counts of Nile tilapia reared at LSD and HSD

\begin{tabular}{llccc}
\hline Parameters & $\begin{array}{l}\text { LSD (treatment) } \\
\text { Mean } \pm \text { S.E. }\end{array}$ & $\begin{array}{l}\text { HSD (treatment) } \\
\text { Mean } \pm \text { S.E. }\end{array}$ & $p$ value & Reference values (specific range) \\
\hline Plasma cortisol level $(\mathrm{ng} / \mathrm{ml})$ & $37.5 \pm 4.6$ & $72.1 \pm 5.9$ & 0.05 & 5-60 Auperin et al. (1997) \\
Blood glucose level $(\mathrm{mg} / \mathrm{dL})$ & $70.2 \pm 1.0$ & $136.00 \pm 1.3$ & 0.05 & $\begin{array}{l}\text { 40.10-80.54 Bittencourt et al. (2003) } \\
\text { 32-137 Mauel et al. (2007) }\end{array}$ \\
Erythrocytes count $\left(10^{6} \mathrm{~mm}^{-3}\right)$ & $2.1 \pm 0.4$ & $7.2 \pm 0.5$ & 0.05 & 1.35-15.21 Bittencourt et al. (2003) \\
\hline
\end{tabular}


Fig. 1 Western blot of plasma GLUT 1 protein (55 kDa) present in HSD and LSD fish. The quantity of GLUT 1 was standardized against the quantity of control ( $\beta$-tubulin)
Fig. 2 Mean relative band intensities for GLUT 1 protein in fish held at HSD and LSD. HSD fish had higher mean rbi for GLUT 1 protein compared to LSD group $(p<0.05)$

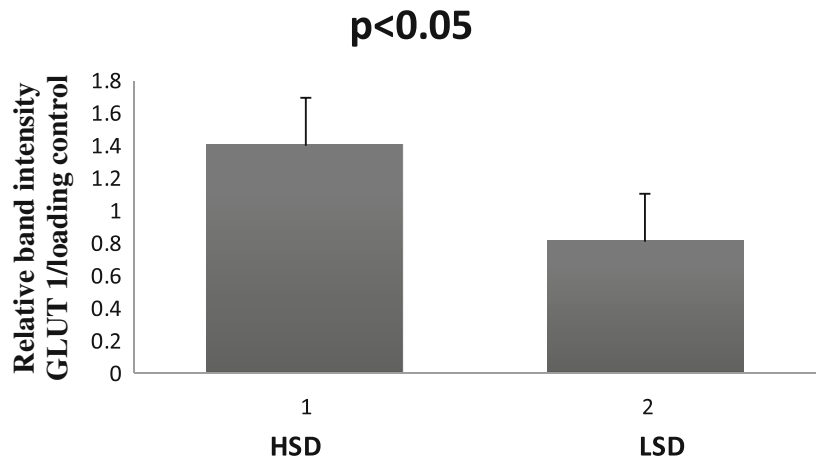

Quantification of Glut 1 protein levels in Nile tilapia

To determine whether HSD had an effect on the levels of expression of GLUT 1 protein, SDS-PAGE western blot analysis was performed on plasma samples from HSD and LSD individuals. The result confirmed the presence of GLUT 1 protein in both HSD and LSD samples (Fig. 1). GLUT 1 protein levels were measured against the constant normal levels and recorded as relative band intensity. HSD individuals had significantly higher mean GLUT 1 protein level than LSD individuals, $p<0.05$. Mean GLUT 1 protein level for HSD group was $\bar{x}=1.40 \pm 0.17$, as compared to $\bar{x}=0.81 \pm 0.07$ of LSD group (Fig. 2).

\section{Discussion}

Effect of stocking density on plasma cortisol level, blood glucose level and erythrocytes count in Nile tilapia

Chronic stress is known to cause adjustments in the levels of cortisol, glucose and erythrocytes of teleost fish. High stocking density induces high energy-consuming activities that include swimming and behaviourial interactions between fish, thus causing competition for resources (Ellis et al. 2002; Lembo and Zupa 2010; Abdel-Tawwab 2012). In the present study, HSD induced chronic stress that was responsible for elevation of plasma cortisol, blood glucose and erythrocytes. This corroborated the observation by Abdel-Tawwab (2012) and Montero et al. (2001), in which elevated stocking density-related stress, raised levels of cortisol, glucose and erythrocytes in Nile tilapia and Gilthead Seabream Sparus aurata. However, the stocking density used in this study was higher than that used by Abdel-Tawwab (2012) and as such it elicited higher values of plasma cortisol, blood glucose and erythrocytes in this study as compared to the corresponding values in the former study. Moreover, the present study used mixed sex juveniles that had not reached sexual maturity and, therefore, sexual behaviors that contribute to stress in cultured fish are not yet expressed at this age in both sexes.

Presently, HSD fish had mean cortisol value that is higher than the mean basal value described by Auperin et al. (1997); and Barreto and Volpato (2006, 2001) as normal for Nile tilapia. Thus, the cortisol data imply that HSD fish were stressed. The reverse was also true for LSD fish. Data on glucose level also indicated that HSD fish were stressed. Glucose levels from this study were compared to the glucose normal range obtained by Bittencourt et al. (2003) for Nile tilapia and found to be higher than the reference range whereas the mean blood glucose level of LSD individuals was within the normal range. However, the two glucose means (LSD and HSD) were within the glucose reference range described by Mauel et al. (2007) for hybrid tilapia 
(Oreochromis aureus $\times$ Oreochromis niloticus). This could be attributed to the differences in the genetic make-up of the fish species and the influence of both ecological and geographical factors. Schreck et al. (2001) also observed that differences in fish species could influence how the species respond to similar stressor.

Erythrocytes count increased with increasing stocking density. However, the erythrocytes counts obtained from HSD and LSD groups fell within erythrocyte count range provided by Bittencourt et al. (2003) for Nile tilapia. The rise in red blood cell numbers in fish held at HSD is similar to patterns described in previous studies (Montero et al. 2001; Bittencourt et al. 2003; Dobšikova et al. 2009; Abdel-Tawwab 2012) in which stress enhanced the numbers of erythrocytes. Falcon et al. (2007) observed that stress lead to elevation of the levels of cortisol that in turn lead to increased erythropoietin concentration stimulating erythrocytes production. That explains the observation in this study that increased number of erythrocytes in the blood was directly proportional to elevated levels of cortisol in HSD group. Therefore, an increase in the numbers of RBCs enhances oxygen-carrying efficiency and the demand of oxygen by cells and tissue (Jawale and Dama 2010). The oxygen molecules are used in the oxidation of substrates leading to the formation of energy, which is then used by the fish to cope with stress (Mommsen et al. 1999).

When fish is exposed to a stressor such as HSD, response is initiated by activation of hypothalamicpituitary-interrenal (HPI) and hypothalamic-chromaffin axes to increase secretion of adrenocorticotropic hormone (ACTH), cortisol and catecholamines in readiness for alleviation of the effect of stress (Wendelaar 1997; Mommsen et al. 1999; Binuramesh et al. 2005). Cortisol is responsible for other ensuing physiological responses to stressors (Sangiao-Alvarellos et al. 2005). In this study, cortisol could have induced increase in glucose and erythrocytes. Cortisol typically promotes mobilization of glucose from energy-rich substrates by depletion of hepatic glycogen stores, and its reallocation to different tissues (Schreck et al. 2001; Dobšikova et al. 2009).

Effect of HSD on expression of GLUT 1 protein

The results obtained indicate that HSD individuals had significantly higher GLUT 1 protein plasma levels than LSD individuals. High stocking density was responsible for high GLUT 1 protein levels in HSD individuals compared to LSD individuals (Fig. 2). Expression of GLUT 1 protein is regulated by extracellular stress (Samih et al. 2000). In this study, HSD acted as a chronic stressor, and therefore modulated the levels of stressinducible GLUT 1 protein. High GLUT 1 protein level in HSD individuals could be due to (1) higher number of erythrocytes which associatively enhanced levels of GLUT 1 protein (a transmembrane protein spanning the membranes of erythrocytes) in HSD individuals, (2) translocation of GLUT 1 protein from the intracellular pool to plasma membrane thereby increasing the level of GLUT 1 protein (Samih et al. 2000).

There was a high blood glucose level corresponding to high GLUT 1 protein level in HSD group. This could imply that GLUT 1 protein is not efficient in transportation of glucose molecules in fish. According to Wright et al. (2000, 1998) and Polakof et al. (2011), teleost fish appear not to have a mechanism to move glucose from bloodstream into muscle and fat tissue or the mechanism of glucose transport from erythrocytes to other tissues which is minimally developed. Also, fish GLUT 1 protein possesses low capacity for glucose clearance from blood in comparison to mammalian GLUT 1 (Wright et al. 1998; Moon 2001).

Implications in fish farming and aquaculture

Increase in blood glucose levels is responsible for provision of energy (fuel) that is used by fish to cope with stress (Pickering and Pottinger 1989; Pickering 1993; Barton 2002). Rectification of the anomaly caused by HSD-related chronic stress necessitates consumption of enormous amount of energy reserve at the expense of other vital physiological functions namely immunity, growth and reproduction (Wendelaar 1997; Barton 2002). This often leads to susceptibility to diseases, reduced growth and decreased reproduction thus diminishing productivity (Pickering 1993; Schreck 1996: Schreck et al. 2001). Therefore, there should be a trade-off between elevated or high stocking densities to boost output and the negative physiological effects that reduce productivity. 


\section{Conclusion}

The results in this study indicate that stocking density of $4.5 \mathrm{~kg} / \mathrm{m}^{3}$ is not suitable for intensive culture of Nile tilapia. Cortisol and glucose data confirmed presence of stress in HSD fish. Also, this study clearly demonstrated that HSD affects the expression levels of GLUT 1 protein in blood. This finding also points to the fact that GLUT 1 protein plays a role in glucose transport in RBCs during chronic stress. Therefore, plasma level of GLUT 1 protein can be used as cellular biomarker for chronic stress in fish. This could provide a more valid data as compared to levels of blood glucose, plasma cortisol and erythrocyte counts which are not suitable when examining chronic stress (Van Weerd and Komen 1998). Since this study has demonstrated that HSD elicits high stress levels that could lead to lowered growth rates as a result of the diversion of energy resources to cope with the ensuing stress, it would be prudent for a farmer to consider the cost-effectiveness of HSD with regard to farm profitability, and to limit their stocking rates at levels below the HSD rates used in this study.

Acknowledgments This research was jointly funded by SIDA through Lake Victoria Research (VICRes) and National Council for Science and Technology (NCST-Kenya) grants to ENW and POA respectively. We are also indebted to Maseno University School of Graduate Studies and to technical assistance provided by staff of Department of Zoology Maseno University.

Open Access This article is distributed under the terms of the Creative Commons Attribution License which permits any use, distribution, and reproduction in any medium, provided the original author(s) and the source are credited.

\section{References}

Abdel-Tawwab M (2012) Effects of dietary protein levels and rearing density on growth performance and stress response of Nile tilapia, Oreochromis niloticus (L.). Intl Aqua Res 4:3

Al Jerian AA (1998) Effect of stocking density on the growth of Oreochromis mossambicus reared in fiber glass tanks. Saudi J Biol Sci 5:9-13

Al-Harbi AH, Siddiqui AQ (2000) Effects of tilapia stocking densities on fish growth and water quality in tanks. Asian Fisheries Sci 13:391-396

Ang'ienda PO, Aketch BO, Waindi EN (2010) Development of all-male fingerlings by heat treatment and the genetic mechanism of heat induced sex determination in Nile Tilapia (Oreochromis niloticus L.). Intl J Biol Life Sci 7:38-42

Auperin B, Baroiller JF, Ricordel MJ, Fostier A, Prunet P (1997) Effect of confinement stress on circulating levels of growth hormone and two prolactins in freshwater-adapted tilapia (Oreochromis niloticus). Gen Comp endocrinol 108:35-44

Balmaceda-Aguilera C, Martos-Sitcha JA, Mancera JM, Martínez-Rodríguez G (2012) Cloning and expression pattern of facilitative glucose transporter 1 (GLUT1) in gilthead sea bream Sparus aurata in response to salinity acclimation. Comp Bioch physiol Part A 163:38-46

Barreto RE, Volpato GL (2001) Environmental blue light prevents stress in the fish Nile tilapia. Brazilian J Med Biol Res 34:1041-1045

Barreto RE, Volpato GL (2006) Stress responses of the fish Nile tilapia subjected to electroshock and social stressors. Brazilian J Med Biol Res 39:1605-1612

Barton BA (2002) Stress in fishes: a diversity of responses with particular reference to changes in circulating corticosteroids. Integ Comp Biol 42:517-525

Barton BA, Iwama GK (1991) Physiological changes in fish from stress in aquaculture with emphasis on the response and effects of corticosteroids. Ann Rev Fish Dis 10:3-26

Binuramesh C, Prabakaran CM, Steinhagen D, Michael RD (2005) Effect of chronic confinement stress on the immune responses in different sex ratio groups of Oreochromis mossambicus (Peters). Aquacult 250:47-59

Bittencourt NLR, Molinari LM, Scoaris DO, Pedroso RB, Nakamura CV, Ueda-Nakamura T, Filho BAA, Filho BPD (2003) Haematological and biochemical values for Nile tilapia Oreochromis niloticus cultured in semi-intensive system. Acta Scientiarum Biol Sci 25:385-389

Boyd CE (1984) Water quality in warmwater fish ponds. Auburn University Agriculture Experimental Station, Auburn

Caipang CMA (2012) Potential molecular biomarkers of crowding stress in Atlantic cod, Gadus morhua and their importance in health management. ABAH Bioflux 4:79-83

Campbell TW (1995) Avian hematology and cytology. Iowa State University Press, Iowa

Chakraborty SB, Mazumdar D, Banerjee S (2010) Determination of ideal stocking density for cage culture of monosex Nile Tilapia (Oreochromis niloticus) in India. Proc Zool Soc 63:53-59

Dobšikova R, Svobodova Z, Blahova J, Modra H, Velišek J (2009) The effect of transport on biochemical and haematological indices of common carp (Cyprinus carpio L.). Czech J Anim Sci 54:510-518

Eames SC, Philipson LH, Prince VE, Kinkel MD (2010) Blood sugar measurement in Zebrafish reveals dynamics of glucose homeostasis. Zebrafish 7:205-213

El-Khaldi ATF (2010) Effect of different stress factors on some physiological parameters of Nile tilapia (Oreochromis niloticus). Saudi J Biol Sci 17:241-246 
Ellis T, North B, Scott AP, Bromage NR, Porter M, Gadd D (2002) The relationships between stocking density and welfare in farmed rainbow trout. J Fish Biol 61:493-531

El-Sayed A-FM (2006) Tilapia culture. CABI Publishing, Oxfordshire

Falcon DR, Barros MM, Pezzato LE, Sampaio FG, Hisano H (2007) Physiological responses of Nile Tilapia, Oreochromis niloticus, fed vitamin C- and lipid-supplemented diets and submitted to low-temperature stress. J World Aquacult Soc 38:287-295

Heidebrecht F, Heidebrecht A, Schulz I, Behrens SE, Bader A (2009) Improved semiquantitative Western blot technique with increased quantification range. J Immuno Meth 345:40-48

Hrytsenko O, Pohajdak B, Xu B, Morrison C, Van Tol B, Wright JR Jr (2010) Cloning and molecular characterization of the glucose transporter 1 in tilapia (Oreochromis niloticus). Genl comp endocrinol 165:293-303

Hwang D-Y, Ismail-Beigi F (2001) Stimulation of GLUT-1 glucose transporter expression in response to hyperosmolarity. Am J Physiol Cell Physiol 281:C1365-C1372

Jawale CS, Dama JB (2010) Haematological changes in the fresh water fish, Cyprinus carpio exposed to sub-lethal concentration of piscicidal compounds from Cestrum species (Family: Solanaceae). Natl J life sci 7(1):81-84

Joost HG, Thorens B (2001) The extended GLUT-family of sugar/polyol transport facilitators: nomenclature, sequence characteristics, and potential function of its novel members (review). Mol Memb Biol 18:247-256

Klepper J, Wang D, Fischbarg J, Vera JC, Jarjour IT, O’Driscoll KR, De Vivo DC (1999) Defective glucose transport across brain tissue barriers: a newly recognized neurological syndrome. Neurochem Res 24:587-594

Laemmli UK (1970) Cleavage of structural proteins during the assembly of the head of bacteriophage T4. Nat 227:680-685

Lembo P and Zupa W (2010) Fish welfare-a key issue for organic system standards. www.ifoam-eu.org. Accessed on 1st June 2014

Mauel MJ, Debra L, Miller DL, Merrill AL (2007) Hematologic and plasma biochemical values of healthy hybrid tilapia (Oreochromis aureus $\times$ Oreochromis nilotica) maintained in a recirculating system. J Zool Wildlife Med 38:420-424

Mommsen TP, Plisetskaya EM (1991) Insulin in fishes and agnathans: history, structure, and metabolic regulation. Rev Aquat Sci 4:225-259

Mommsen TP, Vijayan MM, Moon TW (1999) Cortisol in teleost: dynamics, mechanisms of action, and metabolic regulation. Rev Fish Biol Fisheries 9:211-268

Montero D, Tort L, Robaina L, Vergara JM, Izquierdo MS (2001) Low vitamin E in diet reduces stress resistance of gilthead seabream (Sparus aurata) juveniles. Fish Shellfish Immunol 11:473-490

Moon TW (2001) Glucose intolerance in teleost fish: fact or fiction? Comp Biochem and Physiol Part B 129:243-249

Nakano T, Afonso LOB, Beckman BR, Iwama GK, Devlin RH (2013) Acute physiological stress down-regulates mRNA expressions of growth-related genes in Coho Salmon. PLoS One 8(8):e71421

Pickering AD (1993) Growth and stress in fish production. Aquacult 111:51-63

Pickering AD, Pottinger TG (1989) Stress responses and disease resistance in salmonid fish: effects of chronic elevation of plasma cortisol. Fish Physiol Biochem 7:253-258

Polakof S, Mommsen TP, Soengas JL (2011) Glucosensing and glucose homeostasis: from fish to mammals. Comp Biochem Physiol Part B 160:123-149

Pyla R, Poulose N, Jun JY, Segar L (2013) Expression of conventional and novel glucose transporters, GLUT1, -9, -10, and 12, in vascular smooth muscle cells. Am J Physiol Cell Physiol 304:C574-C589

Salama MEA, Moustafa YT, El-Dahhar AA, Dawah AM (2006) Effect of fertilization on production of Nile tilapia in earthen ponds II) effect of an untraditional organic fertilizer and stocking density on the fish yield of mixed-sex Nile tilapia (Oreochromis niloticus). J Arab Aquacult Soc 1:112-130

Samih N, Hovsepian S, Aouani A, Lombardo D, Fayet G (2000) GLUT 1 Translocation in FRTL-5 Thyroid Cells: Role of phosphatidylinositol 3-kinase and $N$-glycosylation. Endocrinol 141:4146-4155

Sangiao-Alvarellos S, Guzman JM, Laiz-Carrion R, Miguez JM, Del Rio MPM, Mancera JM, Soengas JL (2005) interactive effects of high stocking density and food deprivation on carbohydrate metabolism in several tissues of gilthead sea bream Sparus auratus. J Exp Biol 303A:761-775

Schreck CB (1996) Immunomodulation: endogenous factors. In: Iwama G, Nakanishi T (eds) The fish immune system. Academic, California, pp 311-327

Schreck CB, Contreras-Sanchez W, Fitzpatrick MS (2001) Effects of stress on fish reproduction, gamete quality, and progeny. Aquacult 197:3-24

Van Weerd JH, Komen J (1998) The effect of chronic stress on growth of fish: a critical appraisal. Comp Biochem and Physiol Part A 120:107-112

Wells RMG, Pankhurst NW (1999) Evaluation of simple instruments for the measurement of blood glucose and lactate, and plasma protein as stress indicators in fish. J World Aquacult Soc 30:276-284

Wendelaar BSE (1997) The stress response in fish. Physiol Rev 7:591-625

Wertheimer E, Sasson S, Cerasi E, Ben-Neriah Y (1991) The ubiquitous glucose transporter GLUT 1 belongs to the glucoseregulated protein family of stress-inducible proteins. Cell Biol 88:2525-2529

Wiseman S, Osachoff H, Bassett E, Malhotra J, Bruno J, Van Aggelen G, Mommsen TP, Vijayan MM (2007) Gene expression pattern in the liver during recovery from an acute stressor in rainbow trout. Comp Biochem Physiol D 2:234-244

Wright JR Jr, O'Hali W, Yang H, Han XX, Bonen A (1998) GLUT 4 deficiency and severe peripheral resistance to insulin in the teleost fish tilapia. Gen Comp Endocrinol 111:20-27

Wright JR Jr, Bonen A, Conlon JM, Pohajdak B (2000) Glucose homeostasis in the teleost fish tilapia: Insights from brockmann body xenotransplantation studies. Ame Zool 40:234-245

Zhao FQ, Keating AF (2007) Functional properties and genomics of glucose transporters. Curr Genom 8:113-128 